\title{
Schreber's gardens and Jordan's gardens as elements of created nature: the example of Katowice
}

\section{Ryszard Nakonieczny}

(The Faculty of Architecture, Silesian University of Architecture)

\begin{abstract}
The author analyzes historical examples of allotment gardens as well as sports and recreational grounds in Katowice (Poland) to underscore their importance for the appeal of the city and its ecology. Schreber's and Jordan's gardens of Katowice epitomize broader relationships between the human and nature observed in a typical contemporary city of the $20^{\text {th }}$ century, where nature has crucial significance for the psychological and physical well-being, ensuring one an opportunity for leisure, promoting health, a sense of comfort, as well as activating all senses, which have become dulled today due to the impact of the virtual worlds. The author also outlines his own urban activities, which attempt to draw attention of city dwellers to the advantages of green areas.
\end{abstract}

Key words

everyday aesthetics, Jordan's gardens, Schreber's gardens, urban ecology

Remember the gardens

For that's where you came from In the heat of the age they will bestow the cool shade Only trees, only leaves ${ }^{1}$

We seldom realize the tremendous contribution of allotment gardens and recreational-sports grounds to the charm and ecology of a city. The aim of this paper is to draw attention to that important aspect that ensures city inhabitants aesthetic experience, a sense of comfort, and psycho-physical well-being. The idea dates back to the latter half of the nineteenth century and has left its imprints in many

1 Remember the Gardens, lyrics by Jonasz Kofta, music by Jan Pietrzak. 
regions of Europe, including Upper Silesia and the city of Katowice, which features as the focus of this paper.

\section{Green areas and gardens of Katowice}

Katowice is found in sources for the first time in 1598, as a village established on the river Rawa (Rozdzianka), on the meadows and stretches of land wrestled from nature. The surrounding forests were cleared to provide new land for cultivation and gain access to resources: iron ore, then underground deposits of coal as well as firewood for a metallurgic site was known since the Middle Ages-the so-called Kuźnica Bogucka. In 1865, Katowice was granted city rights 267 years after the first mention of its existence, becoming a rapidly developing center of industry and trade in the Prussian state. As early as 1856, Heinrich Moritz August Nottebohm made a plan of the township, showing the streets, squares, and plots for further development, in which green areas became an important element by way of compensating the residents for the lost contact with nature. ${ }^{2}$ In 1871, Richard Holtze, co-founder of the city and long-standing president of the municipal council, observed that Katowice's green gardens and public squares adjoining the beautiful churches, the rare and often astonishing discoveries of vistas and perspectives, all that captivates and enhances the charms of the city (Holtze 2005, 39).

The city map of Katowice dated 1884 shows a substantial quantity of green areas integrated into its layout (Złoty 2005). There are two parks: one surrounding the palace and another one on a partly drained cooling pond, at the site of a demolished blast furnace (Hochofen) of Kuźnica Bogucka. And there are five squares: Wilhelmsplatz (present-day Plac Wolności), another by the railway station, and three situated near churches - an old Catholic one, an evangelical one, and a Catholic church of the Holy Virgin Mary. They remained under the care of Związek Miłośników Przyrody dla Upiększania Miasta / Verschönerungsverein zur Verbesserung des Stadtbildes durch Baumpflanzungen (the Beautification Society for the Betterment of City Image Through Tree-Planting), established in 1875 (Nałęcz-Gostomski 1926, 89), from which sprang Dyrekcja Ogrodów Miejskich (the Municipal Gardens Directorate), created in $1913,{ }^{3}$ an authority headed until 1932 by an experienced gardener, Paula Sallmann. ${ }^{4}$ In 1888, the suburban Süd Park was laid out outside the city on the grounds of a wild woods leased from the Hohenlohe factory in 1925, it received the name Park im. Tadeusza Kościuszki (Tadeusz Kościuszko Park). The city gradually expanded into open and less urbanized areas south of the railway line built in 1846. Next to dense urban blocks planned for the area, further green areas were designed, such as the garden in Blücherplatz (today's Plac Karola Miarki) and

2 See Hoffmann (2003, 144), Kozina (2005, 44-48).

3 See Nałęcz-Gostomski (1926, 208); Hoffmann (2003, 141).

4 See Piwowarczyk (2015, 410-423). 
Nicolaiplatz (Plac Józefa Rostka). Some of the streets, crisscrossing at right angles, were marked out again to lend them a curved profile and a picturesque course, by means of which urban space became more organic and natural, featuring variable vistas, in accordance with the then highly popular concepts advocated by Austrian urbanist Camillo Sitte (1986, 129-332).

The soft run of the streets was to manifest modernity and herald an encounter with the almost primeval landscape of the Süd Park. The closer to the park on got, the more relaxed the urban structure became, from tenements to detached houses and villas located in extensive private gardens. The last link and, in a sense, a buffer zone connecting urban areas with the park were the so-called Schreber's gardens, ${ }^{5}$ where wooden houses (Gartenlaube) drowned in lush greenery. In this fluid and harmonious manner, one would transition from an urbanized landscape into a forested one. The industrial city thus sought conciliation with nature, from which it had earlier attempted to separate itself.

\section{Schreber's gardens}

The oldest Schreber's garden was created in 1865 in Leipzig (Gryniewicz-Balińska 2015; Pawlikowska-Piechotka 2009), on the initiative of Ernst Innocenz Hauschild, who had established the first association of Schreber's gardens (Schrebergartenverein) only a year earlier. The name was intended to commemorate the achievement of his friend, doctor of medical sciences and orthopedist, Daniel Gottlob Moritz Schreber, who propagated healthy lifestyles and open-air exercise among children and adolescents of industrial cities, as he frequently observed conditions resulting from poor housing standards resulting from rapid and uncontrolled urbanization in the nineteenth century.

Initially, these recreational gardens were intended exclusively for children, with a possibility of minor cultivation for educational purposes. With time, however, they transformed into ornamental-utilitarian gardens directed at their parents, while the recreational-sports function was substantially limited and even wholly overshadowed by the cultivated plots which later predominated. Still, this aspect was never utterly eliminated, as small recreation areas for children would always accompany the comprehensive functional agenda of such gardens.

A similar concept was propagated by Henryk Jordan, from the moment when, in 1888 , he applied to the municipal council of Kraków to be allotted grounds for the creation of a garden where children would be able to exercise and play. The idea was made a reality a year later, in the form of Park Doktora Jordana (Doctor Jordan's Park) - an 8-hectare site with greenery and five sports fields (Śliwowska and Wędrowski 1937, 5-10). Other recreational gardens were soon established

5 These were, in fact, allotment gardens, also referred to as Kleingarten. 

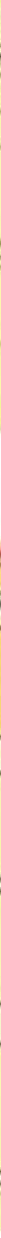

Fig. 1

Plan of Schreber's gardens in Katowice on Barbary Street in 1926 (top) and in 1941 (bottom), retrieved from Plan Wielkich Katowic (Plan of the Great Katowice), 1926, and Gauhaupstadt Kattowitz, 1941. Both from the author's collection

following the example of Kraków: in Nowy Sącz, Kołomyja, Stryj, Częstochowa, Kalisz, Lublin, Środa, Włocławek, Lwów, Cieszyn, and other towns as well.

In 1899, Warszawskie Towarzystwo Higieniczne (Varsovian Society of Hygiene) organized the two first recreation and sports sites for children in Warsaw, specifically in Agrykola Park and in Ogród Saski (Saxon Garden). These were named after Wilhelm Ellis Rau to celebrate the philanthropist and renowned industrialist of Warsaw who endowed the cause with the very substantial sum of 300 ,0oo rubles (Śliwowska and Wędrowski 1937, 10-17). In 1904, there were already 14 gardens of this kind.

Nonetheless, the German Schreber's garden was the first such concept in Europe, and they were introduced outside Leipzig as well, throughout Prussia in fact. The year 1901 saw the first garden of the sort established in Wrocław, in the Fields (Teichäcker) (Gryniewicz-Balińska 2015, 47-50), while the oldest one in Upper Silesia dates back to 1905. It was created in Królewska Huta (part of modern-day 
Chorzów) (Dziesięć lat pracy 1938, 111-113), and has continued to function until the present day on ul. Hajducka. The second appeared in Katowice a year later, in 1906 (A.N. 1935, 155), though in an unofficial form. It was legally sanctioned only in 1909 thanks to the establishment of Towarzystwo Ogrodów Szreberowskich Parku Południowego/ Schrebergartenverein am Südpark (Association of Schreber's Gardens of the Southern Park). The area, on formal lease from the Hohenlohe company, was consistently expanded; in time, it came to be called Kolonią nadinżyniera Hugo Tepelmanna (the Colony of Chief Engineer Hugo Tepelmann), derived from the name of its long-standing president. Today, it is known as Rodzinne Ogrody Działkowe im. Tadeusza Kościuszki (Tadeusz Kościuszko Family Allotment Garden) in Katowice, on ul. Barbary 23.

Its layout follows the shape of the letter $\mathrm{Z}$, with two parallel main alleys intersecting at a slanting angle with a third, arching lane. This is a remnant of the original arrangement, based on the concepts of Sitte. On either side of the avenues there are rectangular allotments whose surface ranges from 200 to $500 \mathrm{~m}^{2}$. A wooden shed or hut could be erected on each, situated well within the perimeter of the plot. Even today, many are a delight to see, retaining their unique and nearly unchanged structure and detail. The principal aesthetics which dominates the architecture of the garden houses is vernacular, spa-like, or Swiss-Tyrolian style, drawing on the 1893 Holzarchitektur, the exemplary publication by architect Bernhard Liebold, though one can also discern other trends, such as a rehashed Baroque classicism designated in German culture as "Um 180o"(around 180o) (Mebes 1908; Helmigk 1937), whose core idea derives from the rational structure of Johann Wolfgang Goethe's Weimarian Gartenhaus. The forms of the Katowice garden houses resemble those exhibited today at Deutsches Kleingärtenmuseum (German Museum of Allotment Gardens) in Leipzig, where the idea was born in 1865. In some cases, they are even more interesting than the latter and thus splendidly complement the museum's collection with new forms. For the most part, the structures found in Katowice underwent little if any transformation; therefore, it would be worthwhile to ensure their immediate protection and to perhaps create an institution equivalent to the one in Leipzig.

An important place in the composition of the entire garden was assigned to the triangular community parcel, intended chiefly as a venue for recreation and exercise for children, where a pond with a fountain, a swing, a merry-go-round, and a bar for gymnastics were put in place (Nałęcz-Gostomski 1926, 244; A.N. 1935, 151; documented in photographs). Regrettably, its erstwhile function has been supplanted by private, ornamental-utilitarian cultivation, while all these facilities have been dismantled and removed. The feature was located at the end of the diagonal avenue (bottom outlier of the letter Z).

The richness of the entire site is reflected in the account of A.N. who observes that in late 1934 the garden "has refurbished outer fences and waterworks, supplying 


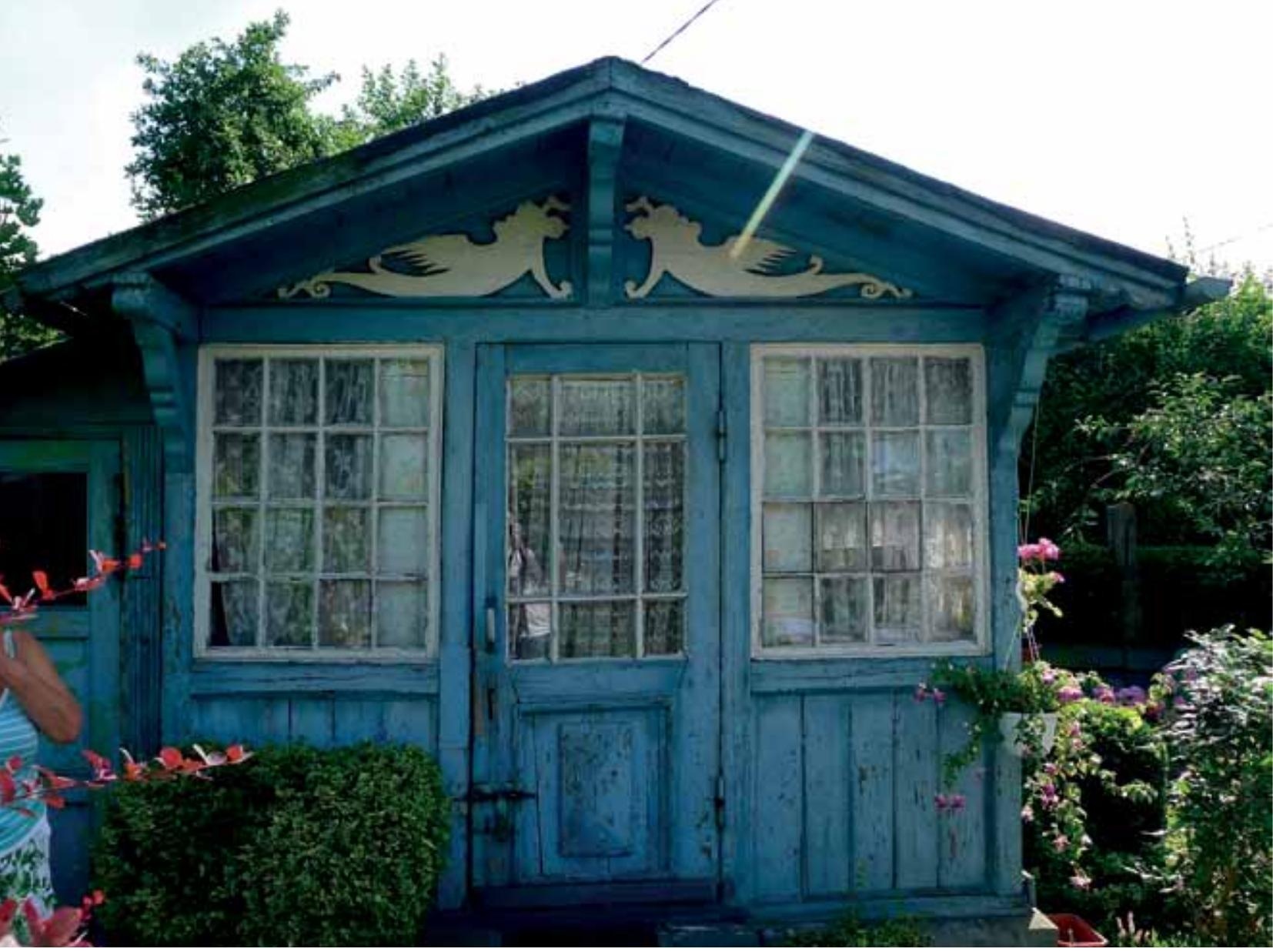

Fig. 2

Bungalow in the Schreber's garden in Katowice on Barbary Street, 2017 Photo by the author 
3.

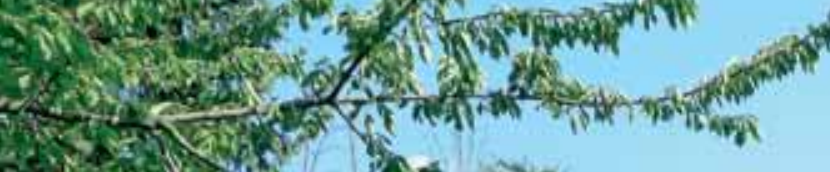



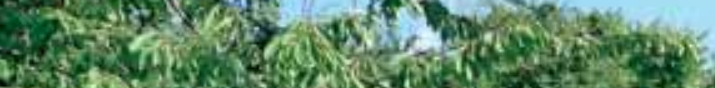

the

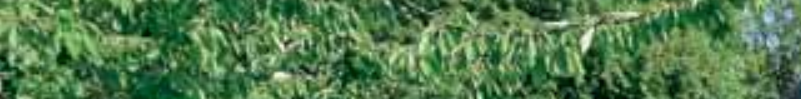

S.

C.

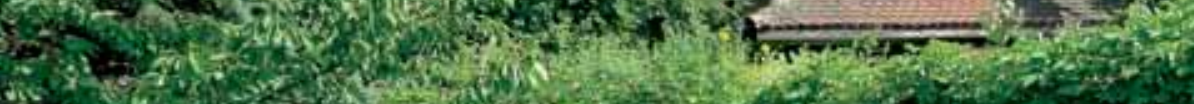

wo

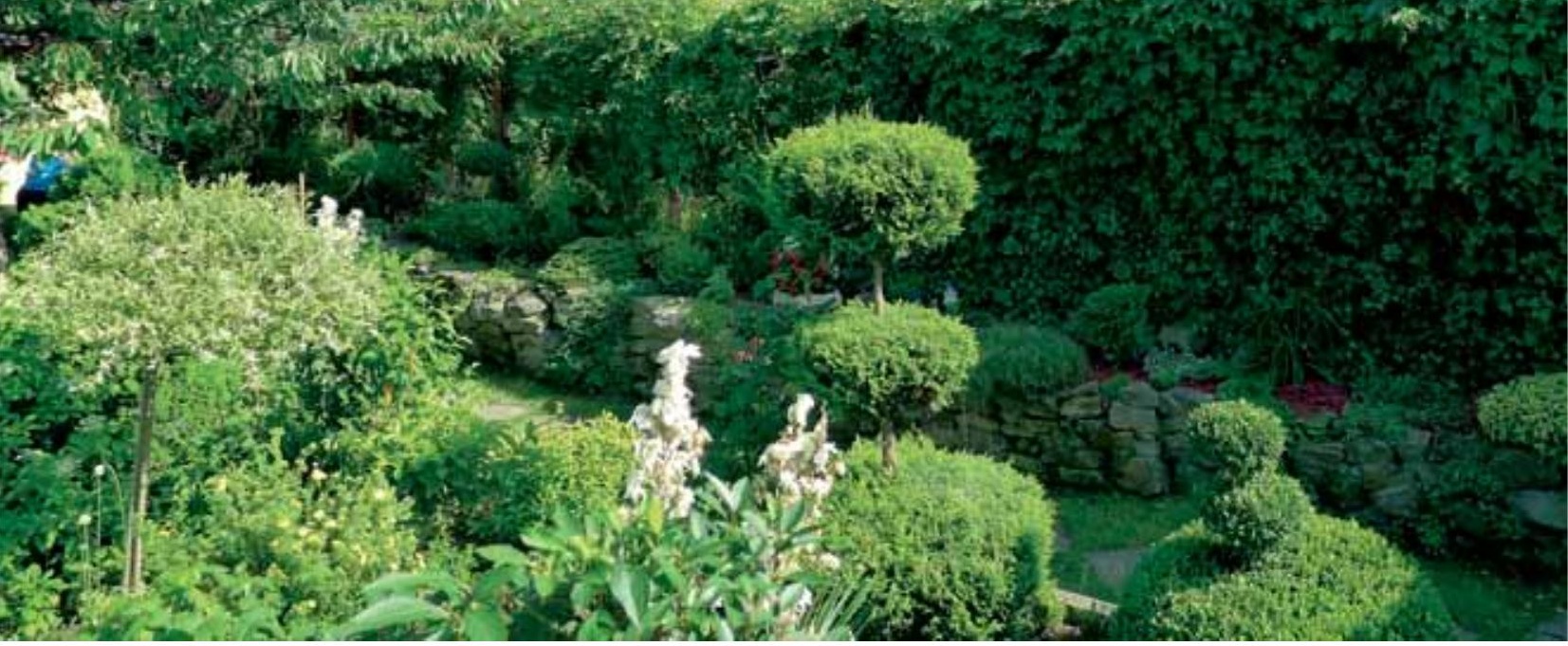

Fig. 5

The Schreber's garden in Katowice on Barbary Street, 2017

Photo by the author 
fresh water to each plot, at a total value of 48,000 zloty, it possesses a community library exceeding 400 volumes, its own sprinkler system and other garden utensils worth 1,00o zloty as well as various exercise equipment and amenities for children to play with and 3,360 zloty of savings in the municipal fund. In the allotments there are also buildings and a special garden adapted to sell milk and beer" (A.N. 1935, 156). The author also adds that the area of the playground and experimental garden for children had been expanded.

The garden in question changed constantly, going through 7 major stages of development which were documented in successive city maps, local regulation plans and designs determining the location of its key facilities, made in 1911, 1915, 1926, 1936, 1939, 1958 and 1972. In the initial phase (1906/1909-1911) the plots were situated only on either side of the main diagonal avenue. In the second stage (1911-1915), new parcels were laid out behind the existing ones, as far as the Beatestrasse (ul. Tadeusza Kościuszki) to the east and Wrangelstrasse (ul. Barbary), leaving a strip of terrain along the street. During the third phase (1915-1926), the acreage of the garden increased by more than twofold, as it was expanded to the west from its oldest part, leaving a considerable expanse of free space between them, in the shape of a four-sided meadow. In the course of the fourth phase (1926-1939), that empty space was put in order and a community playground with a variety of surfaces was created there for general public use. The subsequent fifth stage (1939-1958) begins with the playground being replaced by a new feature, the so-called Jordan's garden, whose official opening took place on May $14^{\text {th }}, 1939.6$ That new and ideologically Polish functional element was thus fused with the genetically German Schreber's garden, not only in view of its central location, but also due to the fact that the previously limited potential of the triangular recreational site for children had been improved. New functional elements appeared, located in the all-year brick facility designed in line with the streamlined style, enabling the original concepts of Schreber's and Hauschild's to be enhanced with a broad range of activities for children inside and outside the building.

That period ends with another, this time a post-war investment, namely the lottery office of the so-called Dom Służewca (Służewiec House), ${ }^{7}$ which was commissioned in 1958 and followed the functional streamlined style of the pavilion in the Jordan's garden and facilities at the Służewiec horseracing track in Warsaw, from which it took its name. It was built at the juncture with the southern boundary of the oldest part of the garden. At that point, one had to face the inevitable threat of the new vehicle thoroughfare, which irretrievably separated the formerly organically linked elements of Kościuszko Park and the Schreber's garden. Some time earlier,

6 Photographs in the collection of the National Digital Archives: 1-N-285-1, 1-N-285-2, 1-N-285-3, 1-N-285-4, 1-N-285-1 and designs kept in the city hall archives in Katowice, ref. no. A $1 / 82$.

7 Disused today, it had until recently served as the premises of "Galop," an eating establishment designed in 1956 by architect Roman Rudniewski and construction engineer Franciszek Klimek. 
the name of the garden had been changed to "allotment" garden, ${ }^{8}$ a name maintained by Germans throughout the occupation period (1939-1945). Today, nobody uses the original, historical name. The final period (1958-1972?) saw a reduction of the overall surface and a decrease in the number of parcels. The area to the west was liquidated completely and left fallow, which may have owed to the development of the road network and replacement of the nearby Rondo Mikołowskie (Mikołowskie Roundabout) with flyovers and traffic separation bridges, which took up much of the new area. Today, Rodzinne Ogrody Działkowe im. Tadeusza Kościuszki is limited to the surface it had before 1915, being almost completely cut off from the park. Only a narrow overpass for pedestrians and bicycles suspended above the A4 motorway connects areas which had once constituted an integrated entity. Furthermore, the liquidation of the western section of cultivated plots created a situation where the Jordan's garden, previously a central feature, is now located at the margins, creating a sense of isolation among the unaware. Nowadays, nobody remembers that these elements were connected by one idea, all the more so that the designation of "Jordan's garden" was changed in 1971 to Miejskie Przedszkole nr 3 (municipal kindergarten No. 3) in Katowice.

\section{Jordan's gardens}

As already observed, the first Jordan's garden was established in 1889 on the initiative of Henryk Jordan in Kraków, so as to give children the opportunity to "play freely in the open air and sun, in good hygienic conditions" (Śliwowska and Wędrowski 1937, 2). The revival of the concept, which later faded somewhat into obscurity, should be attributed to Colonel Juliusz Ulrych, director of the Państwowy Urzęd Wychowania Fizycznego i Przysposobienia Wojskowego (PUWF i PW) (State Office for Physical Education and Military Pre-Training). In 1927, Ulrych was in charge of the closedown of the International Sanitary Exhibition, which had been organized on the military grounds in Warsaw at the junction of ul. Bagatela and al. Ujazdowska. He petitioned Marshall Józef Piłsudski to allot the area for a model children's garden, to which Piłsudski immediately consented. Thus, as of 1928, the matter was within the competence of Ulrych's office. However, the first Jordan's garden was officially commissioned only in 1929 at the site where Warszawskie Towarzystwo Ogrodów Jordanowskich (Warsaw Society of Jordan's Gardens) was established in 1932, becoming a nationwide institution two years later. Still before the latter change, the organization created 9 further gardens in the capital. In other cities, such as Poznań, Łódź, Lwów, and Katowice, similar undertakings were coordinated by the city boards or their respective garden departments. Thanks to the initiative of Centralne Towarzystwo Ogrodów Działkowych (Central Society

8 The debate concerning the naming was reported by anonymous author K-ski (1937). 


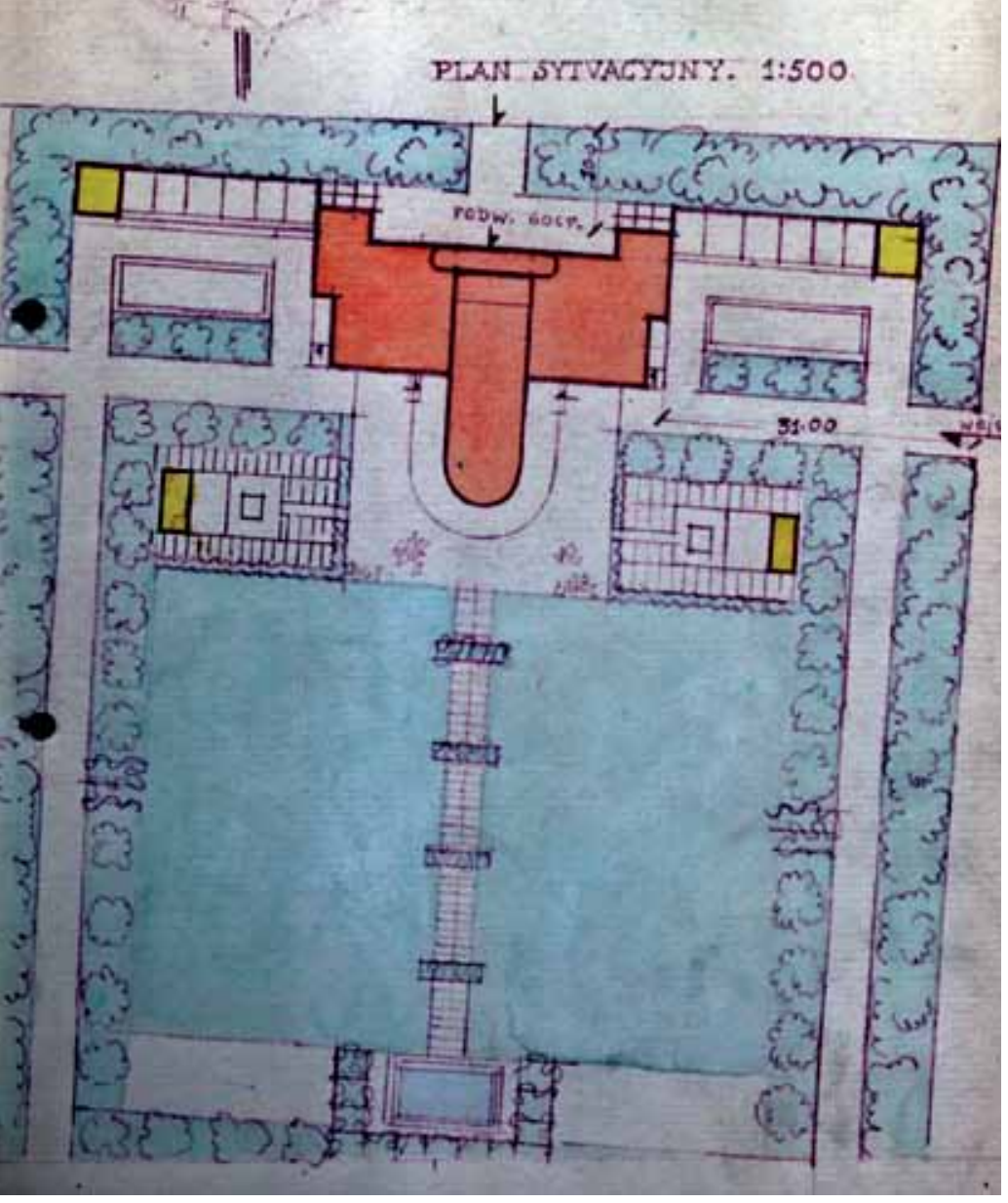

Fig. 6

Plan of Jordan's garden in Katowice on Barbary Street, 1937, designed by Kazimierz Wędrowski From Archiwum Urzędu Miejskiego w Katowicach, cat. no. A 1/82.

of Allotment Gardens) and the PUWF i PW, the year 1937 saw the publication of a fundamental handbook and compendium relating to the establishment of recreational gardens for children in Poland, entitled Ogrody Jordanowskie (Jordan's gardens). The volume was written by Helena Śliwowska, ${ }^{9}$ scoutmaster of the Republic of Poland and head of thefemale division ZHP (polish scouting), and architect Kazimierz Wędrowski. In 1938, Śliwowska married Michał Grażyński, the governor of the region, which may have had considerable impact on the extensive initiatives aimed at building Jordan's gardens on the territory of the autonomous

9 See also Kozina (2010, 77). 


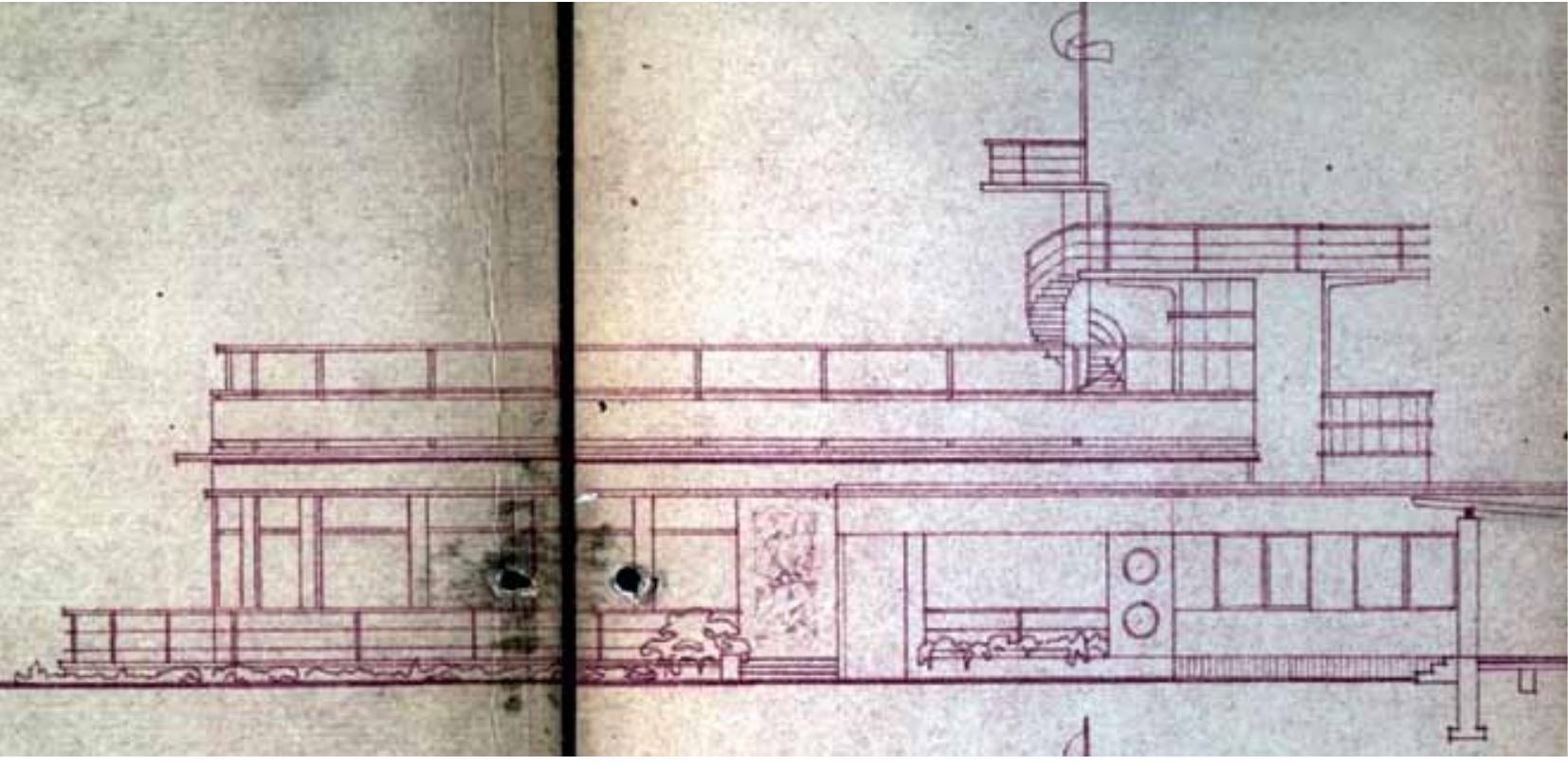

Fig. 7

Eastern façade of the bungalow in Jordan's garden in Katowice on Barbary Street, 1937, designed by Kazimierz Wędrowski

From Archiwum Urzędu Miejskiego w Katowicach , cat. no. A 1/82

province of Silesia that her husband administered. As many as 14 Jordan's gardens had been planned in 1937, including 4 in Katowice (Kozina 2010, 17). At least 7 complexes created as part of that undertaking have survived almost in their entirety: in Katowice (ul. Barbary 25, ul. Gliwicka 212-214, ul. Hallera 72), Mikołów (ul. Konstytucji 3 maja 38), Radzionków (ul. Gajdasa 1), Siemianowice Śląskie (ul. Chopina 2), and Świętochłowice (ul. Harcerska 1) (Nakonieczny 2010).

At least two of the gardens in Katowice were combined into one spatial layout with allotment gardens, by way of adding to their core concept. One of those is the Schreber's garden adjoining Kościuszko Park. The other is the allotment "Świt," established in 1935 in the quarter of Załęże, on ul. Wojciechowskiego (present-day ul. Gliwicka 233), which was attached to the large-surface Jordan's garden across the street (ul. Gliwicka 212-214), where one found a kindergarten building, a janitor's lodge, a reinforced-concrete feature providing visual identification (comprising three flagpoles with representations of three horses), two locker room pavilions, two pools, and numerous smaller structures located throughout its extensive, open grounds.

The Jordan's garden on ul. Barbary 25 was designed by Kazimierz Wędrowski in 1937 and boasted a similarly sophisticated layout composed of surviving brick facilities: the main building, the caretaker's lodge, and the reinforced-concrete entrance gate. The no-longer extant elements include two elongated arcades ending with storehouses, two pergolas, and at least two fountain pools, which were laid out on a large meadow bordered with tall greenery. The entire composition is symmetrical for two reasons: in order to facilitate a balanced division of functions 
in the buildings and in the garden into sections for boys and girls, as well as due to the same treatment of the communication route leading to the Schreber's gardens to the east and west. The main building to the north is provided with a basement and access to necessary facilities: a boiler room, fuel depot, kitchen, workshops, and storehouses. The blueprint shows that the ground floor comprised a hallway, children's changing room, showers, dining room, playroom, a stairway connecting all the storeys (basement, first, and second floor), administration rooms, a doctor's office, and an apartment for the janitor. On the first floor there is also a large solarium-terrace, a smaller northward terrace, a roofed deckchair area, and a storeroom for deckchairs. Regrettably, the spiral stairs leading to the terrace above the deckchair area have not survived; from that terrace, one could once climb an iron ladder to the so-called swallow's nest-a small observation deck with a flagpole. The layout of the building is roughly T-shaped, where the vertical element is a rectangle with its bottom side rounded; this is where the two largest interiors are found: the dining room and the playroom. The horizontal body of the building includes three glazed cylindrical forms, which together with the banisters and round windows were to resemble a modern ship or fishing vessel. The structure of the caretaker's lodge featured similar elements. The nautical architecture of both is a synonym for machinism, whose core idea was to ensure rational and economical assignment of functions, simultaneous minimization of expenditure, reliability of the building, and a balance between functional and formal components. Neutral (i.e., glazed as extensively as possible), transparent, white, and smooth architecture consisting of straight, angular, or streamlined forms was to have a similar effect on the imagination of the child as building blocks do. Its aim was to educate, radiating a clear and straightforward message about basic shapes and solids, without the disruption caused by ornaments, texture, and color.

Wędrowski did not accomplish all of his objectives, given that he planned to place a figural composition of a dancing highlander at the entrance on the garden's side; although the feature is included in the design, it was most likely never made. The serenity and clarity of the structure sets the buildings apart from the wealth of color and unpredictable shapes of the organic surroundings. Thanks to a large number of apertures, arcades, terraces, and pergolas, they blur the distinction between the interior and exterior, once again restoring a maximum of nature to culture. It appears to have been a deliberate, comprehensive educational agenda presupposing an impact on both young and adult observers or users. The contrast of white architecture produces a non-invasive and maximally neutral backdrop to the spectacle of natural events, so as to highlight its momentous role in the garden-therapeutic and aesthetic alike. "Thus, nature in the garden performs practical roles and communicates various meanings, yet at the same time-by virtue of human action-it fulfils an aesthetic function as well," as Mateusz Salwa $(2016,85)$ summed it up. 


\section{Conclusions}

The Schreber's and Jordan's gardens of Katowice encapsulate broader relationships between humans and nature, observed in a typical, modern, twentieth-century city, where nature was crucial to the psycho-physical balance of its residents-not only ensuring leisure opportunities, health, and a sense of comfort, but also offering a possibility of activating all their senses, which have become so shallow in today's world of virtual reality. Therefore, restoring or increasing the share of nature-both wild and controlled nature-in an urbanized environment remains a vital issue. Also, we should not destroy the outcomes of actions undertaken in the past to achieve that end; we should preserve the accomplishments we have inherited from previous generations. Regrettably, green areas in cities continue to dwindle, consumed by new development projects. In order to draw the attention of the community to the significance of urban greenery in Katowice (among other things), Wojtek Siegmund and I have embarked on a grassroots initiative and, having organized multiple events, succeeded in registering the Dom Modernisty foundation. ${ }^{10}$ Its foremost aim includes encouraging inhabitants to action by discovering the potential and value of their place of residence. By June $10^{\text {th }}, 2017$, we had organized 11 meetings, including 10 in the series Festiwal Ogrodów (festival of gardens), which consists in monthly lectures combined with walks; their themes consistently explored the interactions between three subjects: humans, architecture, and nature. Invariably, the meetings translate into greater knowledge gained by both the speakers and the participants. The first edition of the Festival of Gardens, focusing on green modernism, took place on August $20^{\text {th }}$, 2016. I prepared three walks covering the gardens in a southern quarter of Katowice, one Jordan's and one Schreber's garden as well as three villa gardens: Anton Zimmermann's, created in 1907, Michał Zieliński's (1925-1927) and Zygmunt Zuurawski's (1927-1931). This paper presents some of the information obtained in the course of my research which was communicated at the time to the participants.

The project was subsequently submitted to Otwarty konkurs ofert na zadania publiczne województwa ślaskiego w sferze działań na rzecz zachowania wielokulturowości regionu oraz kultury mniejszości narodowych ietnicznych w 2017 roku (Open Competition for Public Tasks of the Silesia Region to Preserve Multiculturality of the Region and Cultures of National and Ethnic Minorities in 2017), held by the marshal'soffice of Silesia. As a result, we received a subsidy of 8,000 PLN to organize an openair exhibition entitled Ślady wielokulturowości Górnego Śląska na przykładzie ogrodów szreberowskich i jordanowskich (Multicultural Traces in Upper Silesia, on the Example of Schreber's and Jordan's Gardens in Katowice), taking place from September $15^{\text {th }}$ to December $9^{\text {th }}$ 2017. The exhibition consisted of panels

10 See http://dommodernisty.org.pl. 


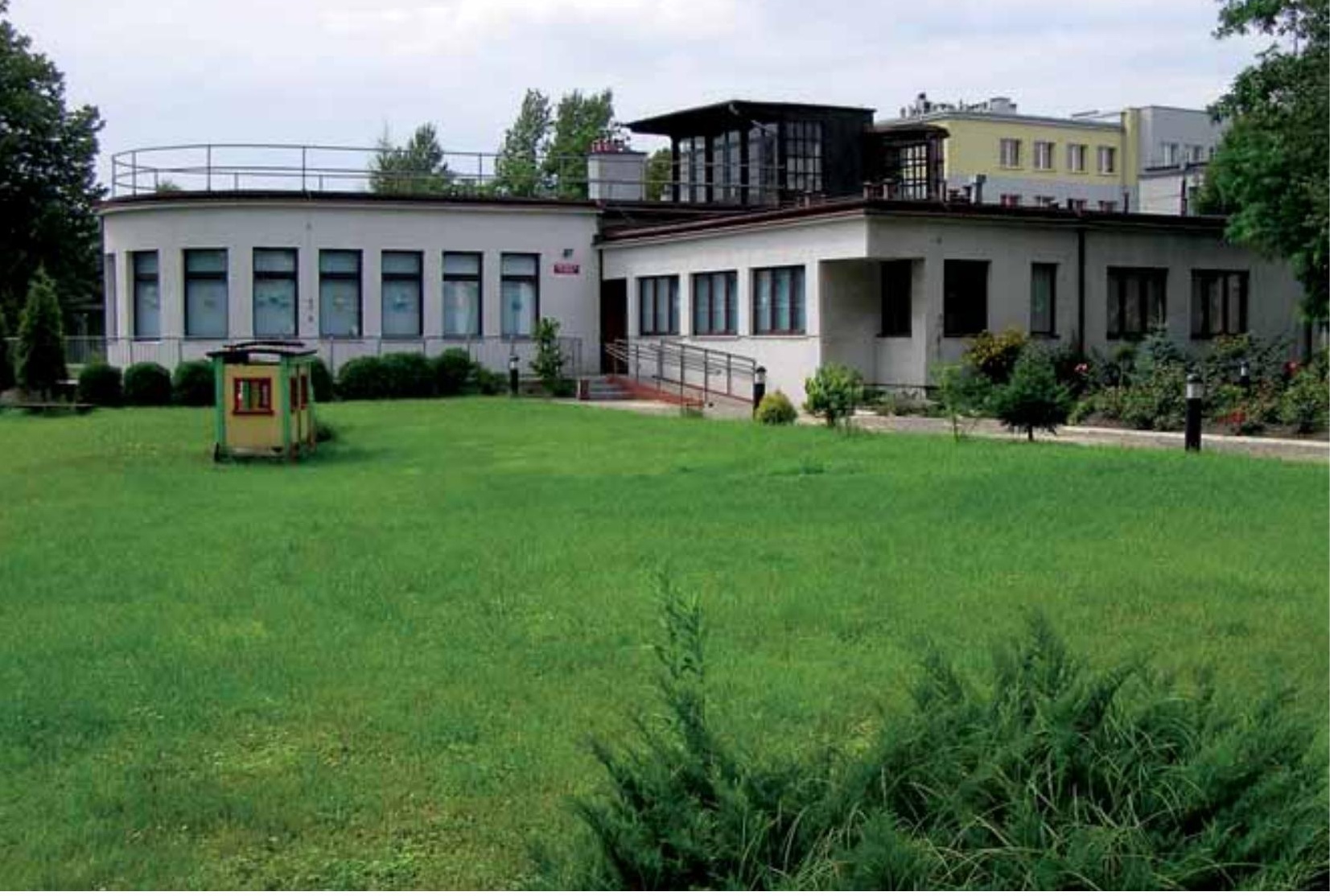

Fig. 8

Bungalow in Jordan's garden in Katowice on Barbary Street seen from the south-east, 2017

Photo by the author

outlining the origins of the gardens, their goals, and their later fates, displayed on the grounds of the allotment gardens and kindergarten area. The public had free and unconstrained access to the exhibition. Furthermore, two meetings are planned to gather local community and elicit a discussion concerning the history of gardens. The meetings will be held in the community club at Park im. Tadeusza Kościuszki (Tadeusz Kościuszko Park) in Katowice. A guided tour of the gardens and the surviving period garden houses has been planned as well.

In 1934, the governor of Silesia, Michał Grażyński, meaningfullys tated that "allotment gardens add beauty to our industrial landscape, bring people closer to nature, giving them opportunity to forget the daily concerns and toil of professional work, let them breathe deeper, evoking a smile of joy with the crops they reap. It enables them to feel closer to what is called 'the blessing of earth"'(1934, 81). The verses sung by Jonasz Kofta, who in 1952 lived in a Katowice villa with a large extensive garden at Gen. Zajączka 10, in the vicinity of a Schreber's garden, also do not seem to have lost their relevance: "Remember the gardens, / for that's where 
you came from. / In the heat of the age they will bestow the cool shade. / Only trees, only leaves." Might it be that these words recall the Katowice garden of his childhood?

\section{References:}

Dziesięć lat pracy Okręgowego Związku Towarzystw Ogrodów Działkowych i Osiedli województwa śląskiego 1928 - 38 [A Decade of the Regional Association of Allotment and Estate Societies in the Silesian Voivodeship 1928-38]. 1938. Chorzów: Zakłady Graficzne Leopold Nowak.

Grażyński, Michał. 1934. "Cieszę się niezmiernie..." ["I am really glad..."]. Śląski Działkowiec 10.

Gryniewicz-Balińska, Katarzyna. 2015. "Historyczne ogrody działkowe Wrocławia jako element planowanego systemu zieleni miejskiej" ["Historical Allotments in Wrocław as an element of planning urban greenery"]. Kwartalnik Architektury i Urbanistyki 60/1, 45-79.

Helmigk, Hans-Joachim. 1937. Oberschlesische Landbaukunst um 1800. Leipzig: G. Kreysing. Hoffmann, Georg. 2003. Historia miasta Katowice [The History of the City of Katowice]. Translated by Dariusz Makselon and Michał Skop. Katowice: Muzeum Śląskie.

Holtze, Richard. 2005. Miasto Katowice. Studium kulturalno-historyczne [The City of Katowice: A Cultural and Historical Study]. Translated by Irena T. Sławińska. Katowice: Muzeum Śląskie.

Kozina, Irma. 2005. Chaos i uporządkowanie. Dylematy architektoniczne na przemysłowym Górnym Śląsku w latach 1763 - 1955 [Chaos and Order: Architectural Dilemmas in Industrial Upper Silesia in 1763-1955]. Katowice: Wydawnictwo Uniwersytetu Śląskiego.

Kozina, Irma. 2010. "Modernistyczne Gesamtkunstwerk, a koncepcja ogródków jordanowskich w Katowicach dwudziestolecia międzywojennego" ["Modernist Gesamtkunstwerk and the Concept of Jordan's Gardens in Katowice in the Two Decades Between the World Wars]. Archivolta 1(45) 2010, 46-78.

K-ski. 1937. "Ogrody szreberowskie czy ogrody dziatkowe"["Schreber's Gardens o Allotments"]. Dziatkowiec Śląski 8

Liebold, Bernhard. 1893. Holzarchitektur. Taschenbuch für Bauhandwerker. Holzminden: C. C. Müllersche Buchhandlung.

Mebes, Paul. 1908. Um 1800. Architektur und Handwerk im Letzten Jahrhundert ihrer traditionellen Entwicklung. Munich: F. Bruckmann A.-G.

N., A.. 1935. "Wędrówka po ogrodach działkowych na Górnym Śląsku I, II" ["A Trip Around Allotments of Upper Silesia I, II”]. Śląski Działkowiec 14-5.

Nakonieczny, Ryszard. 2010. "Awangarda dla najmłodszych, czyli corbusierowskie okręty w ogrodach jordanowskich Górnego Śląska" ["Avant-garde for the Youngest, or Le Corbusier's Ships in the Jordan's Gardens of Upper Silesia"]. Archivolta no. 1(45), 79-82.

Nałęcz-Gostomski, Władysław. 1926. Dzieje i rozwój Wielkich Katowic jako ośrodka górnośląskiego przemystu i stolicy autonomicznego województwa śląskiego [The History and Development of Greater Katowice as the Upper Silesian Industry Center and the Capital of the Autonomous Silesian Voivodeship]. Katowice: Magistrat Wielkich Katowic. 


\section{Ryszard Nakonieczny}

Pawlikowska-Piechotka, Anna. 2009/2010. "Ogrody działkowe w przestrzeni miasta" ["Allotment Gardens in Urban Space"]. Archivolta 3(43) 2009, 81-2; 1(45), 84-7.

Piwowarczyk, Przemysław. 2015. "Dyrektor ogrodów miejskich Paul Sallmann i ogrodnictwo miejskie w międzywojennych Katowicach" [Director of city gardens Paul Sallmann and urban gardening in Katowice in the interwar period]. In Katowice w II Rzeczypospolitej [Katowice in the Second Polish Republic], edited by Antoni Barciak. Katowice: PAN Oddział Katowice.

Salwa, Mateusz. 2016. Estetyka ogrodu. Miedzy sztuką a ekologią [Garden Aesthetics: Between Art and Ecology]. Łódź: Wydawnictwo Przypis.

Sitte, Camillo. 1986. The Birth of Modern City. New York: Rizzoli.

Śliwowska, Helena and Wędrowski, Kazimierz. 1937. Ogrody Jordanowskie [Jordan's gardens]. Warsaw: Główna Księgarnia Wojskowa.

Złoty, Andrzej. 2005. Mapy i plany Katowic [Maps of Katowice]. Katowice: Miejski Dom Kultury Południe, Bractwo Gospodarcze Związku Górnośląskiego. 